\title{
The Comparison of the Long-Term Efficiency of Short Columellar Strut Graft and Suture Techniques on Maintaining Nasal Tip Projection and Nasolabial Angle Following Primary Open Rhinoplasty
}

\author{
Primer Açık Yaklaşım Rinoplastide Burun Ucu Projeksiyonu ve Nazolabiyal Açının \\ Uzun Dönem Korunmasında Sütür Teknikleriyle Greft Tekniklerinin Etkinliğinin \\ Karşılaştırılması
}

(D) Dinçer Altınel, (D) Gaye Toplu, (D) Merdan Serin

University of Health Sciences Turkey, İstanbul Training and Research Hospital, Clinic of Plastic Surgery, İstanbul, Turkey

\begin{abstract}
Introduction: We aimed at comparing nasal tip projection and nasolabial angle changes following primary open rhinoplasty with short-floating columellar strut graft and suture techniques.

Methods: Participants were divided into two groups depending on the type of technique employed. In the first group, shortfloating columellar strut grafts were employed. The second group involved those who underwent suture techniques only.

Results: We included 119 patients who underwent primary rhinoplasty in the study. The mean value of preoperative nasolabial angle measurement was $92.77 \pm 8.5$ degrees and 92.14 \pm 6.7 degrees in groups 1 and 2, respectively. Postoperative nasolabial angle measurement in group 1 was $107.2,104.3$ and 101.3 degrees in the $1^{\text {st }}, 3^{\text {rd }}$, and $5^{\text {th }}$ postoperative year, respectively. Postoperative nasolabial angle measurement in group 2 was 107.4, 104, and 102.2 degrees in the $1^{\text {st }}, 3^{\text {rd }}$, and $5^{\text {th }}$ postoperative year respectively. The mean value of preoperative nasal tip projection was $0.605 \pm 0.07$ and $0.653 \pm 0.08$ in groups 1 and 2 , respectively. Postoperative nasal tip projection measurement in group 1 was $0.636,0.632$ and 0.627 in the $1^{\text {st }}, 3^{\text {rd }}$, and $5^{\text {th }}$ postoperative year, respectively. Postoperative nasal tip projection measurement in group 2 was $0.656,0.634$ and 0.632 in the $1^{\text {st }}, 3^{\text {rd }}$, and $5^{\text {th }}$ postoperative year, respectively.
\end{abstract}

Conclusion: Suture techniques were efficient than columellar strut grafts in maintaining the nasolabial angle but not the nasal tip projection when.

Keywords: Rhinoplasty, nasolabial angle, nasal tip projection

\section{öZ}

Amaç: Bu çalıșmanın amacı, primer açık yaklașım rinoplasti sonrası burun ucu projeksiyonunu ve nazolabiyal açı değișikliklerini short-floating kolumellar grefti ve sütür teknikleriyle karşılaştırmaktır.

Yöntemler: Hastalar burun ucu modifikasyonu için kullanılan tekniğin türüne göre iki gruba ayrıldı. Birinci grupta shortfloating kolumellar greftler kullanıldı. İkinci grupta sadece dikiş teknikleri kullanıldı.

Bulgular: Çalışmaya 119 primer rinoplasti hastası dahil edildi. Preoperatif nazolabiyal açı ölçümünün ortalama değeri grup 1 ve grup 2'de sırasıyla; 92,77 $\pm 8,5$ ve $92,14 \pm 6,7$ derece idi. Grup 1'de postoperatif nazolabiyal açı ölçümü postoperatif 1., 3. ve 5. yılda sırasıyla 107,2, 104,3 ve 101,3 derece idi. Grup 2'de postoperatif nazolabiyal açı ölçümü postoperatif 1., 3. ve 5. yılda sırasıyla; 107,4, 104 ve 102,2 derece idi. Preoperatif burun ucu projeksiyon ölçümü ortalama değeri grup 1 ve grup 2'de sırasıyla; $0,605 \pm 0,07$ ve $0,653 \pm 0,08$ idi. Grup 1'de ameliyat sonrası burun ucu projeksiyon ölçümü ameliyat sonrası 1., 3. ve 5 . yılda sırasıyla; $0,636,0,632$ ve 0,627 idi. ikinci grupta postoperatif burun ucu projeksiyon ölçümü ameliyat sonrası 1., 3. ve 5 . yılda sırasıyla $0,656,0,634$ ve 0,632 olarak hesaplandı.

Sonuç: Sütür tekniklerinin nazolabiyal açıyı korumak açısından etkili olduğunu, ancak kolumellar greftlerine kıyasla burun ucu projeksiyonunu sürdürmede etkisinin daha az olduğu anlaşılmaktadır.

Anahtar Kelimeler: Rinoplasti, nazolabial açı, burun ucu projeksiyonu
Address for Correspondence/Yazıșma Adresi: Merdan Serin MD, University of Health Sciences Turkey, İstanbul Training and Research Hospital, Clinic of Plastic Surgery, İstanbul, Turkey

Phone: +90 5067035515 E-mail: merdanserin@gmail.com ORCID ID: orcid.org/0000-0002-1257-0591

Cite this article as/Atıf: Altınel D, Toplu G, Serin M. The Comparison of the Long-Term Efficiency of Short Columellar Strut Graft and Suture Techniques on Maintaining Nasal Tip Projection and Nasolabial Angle Following Primary Open Rhinoplasty. İstanbul Med J 2021; 22(4): 261-6.

(C) Copyright 2021 by the University of Health Sciences Turkey, Istanbul Training and Research Hospital/Istanbul Medical Journal published by Galenos Publishing House.

(C) Telif Hakkı 2021 Sağlık Bilimleri Üniversitesi İstanbul Ĕgitim ve Araştırma Hastanesi/istanbul Tıp Dergisi, Galenos Yayınevi tarafından basılmıștır.
Received/Geliş Tarihi: 27.04.2021 Accepted/Kabul Tarihi: 01.08.2021 


\section{Introduction}

Rhinoplasty is one of the most common procedures performed by plastic surgeons, otolaryngology specialists, and maxillofacial specialists (1). These procedures are performed for reconstructive and esthetic purposes. Various nasal deformities may develop in patients as a result of posttraumatic injuries, congenital anomalies, and previous failed operations. These deformities cause possible difficulties in breathing in such patients. Functional problems can occur either alone or combined with disfigurement noticeable in external view. Rhinoplasty procedures have been under constant change and improvement throughout history.

One of the most difficult surgical stages is the part related to tip shaping, projection, and rotation (2). In previous studies, the measurements of nose dorsal length, columellar length, lobular length, nasocolumellar, and nasolabial angles were evaluated to enable the proper analysis of changes in nasal rotation and projection (3). In some of the procedures for tip shaping, rotation, and projection, supportive grafts were employed, and in some, combined techniques were employed (4-7).

The main goal of rhinoplasty is to improve the functionality of the nose as well as the structure (8). In other words, keeping the nasal airway passage is mainstay aims of this procedure. The surgery can either be approached through a closed or open technique. In general, open technique is more often employed. Although closed technique cannot be employed to any nose, it is beneficial for surgeons to know and apply both techniques (8). Prior to rhinoplasty, planning is made according to the face tip of the person, and the nose cartilage, bone, soft tissue, and skin are reshaped (9).

Preparation for rhinoplasty starts with the evaluation of the detailed patient history, detailed examination of the nasal airway, and nasofacial analysis of the patient. It is also important for the surgeon to understand the patient's expectations as well as determine the patient's compliance with this procedure. Eating habits should be checked, in order to predict conditions such as post-operatory ecchymosis bleeding can be more easily predicted (10). External valve, internal valve, conchae, and septum should be carefully examined for the evaluation of nasal airway. The presence of collapse was analyzed with the help of a speculum and by performing a deep inspiration (9). Deviation, tilt, spur formation, perforation, polyp, and tumoral masses should be noted (10). Paranasal computed tomography or other imaging methods should be taken in patients who are deemed necessary.

In rhinoplasty, alterations and corrections of the bone-cartilage roof, nasal dorsum, septal deviation, nasal tip shape, nasal floor, alar wings, tip rotation, alar flaring, columella, nostril, nasal projection are performed $(1,4,8,10,11)$. It is performed under general anesthesia mostly except for some limited tip plasties. During the procedure, local solutions with adrenaline are injected to reduce the risk of bleeding in the surgical field. If we are careful during the local injection, unwanted consequences such as trigeminal cardiac reflex are prevented (12).

Tip shaping, which is one of the most important parts in rhinoplasty, should be to obtain a nose tip suitable for the patient's face and general nose shape. Nose tip has unique skin and cartilage structure, contours and curved shape (alar wing, and columella). Various types of suture techniques and graft types are used in tip shaping to obtain an appropriate stability and angle of the nose tip. Columellar strut grafts are frequently employed among other tip grafts such as lateral crural strut grafts, alar rim grafts, alar batten on-lay grafts, shield grafts, tipon-lay grafts, floating grafts, caudal septal extension grafts $(11,13)$. As revealed in the anatomical studies, a number of ligamentous structures are important for the structure nasal tip (14-16). Nasal tip skeletal cartilage structure is mainly formed of the caudal part of the septum and the alar cartilage structure. It should also be noted that nasal tip has its own tripod structure. Nasal tip changes can be made with surgical maneuvers in these structures. Tip defining points can be rearranged with resection or extension maneuvers performed medially, laterally, intermediate crus or septal distally. In addition, the projection can be reduced and increased (16-18). In primary rhinoplasty cases, the underlying anatomical causes of tip asymmetries are frequently the deformities in caudal septum, lower lateral cartilage, and anterior nasal spine $(19,20)$. The excessive resection of the support cartilage tissue can also produce asymmetrical results $(21,22)$.

\section{Methods}

This was a retrospective study. The study was approved by the University of Health Sciences Turkey, İstanbul Training and Research Local Ethics Committee (approval number: 2802, date: 16.04.2021). Informed consents granted by all patients. Patients operated for primary rhinoplasty with mild and moderate deformities between the years 2011 and 2015 were included in the study. Those with severe columellar and alar deformities, severely weak and asymmetric lower lateral cartilages and severely under projected nasal tips, where techniques such as tip grafting or septal extension might be required, were excluded from the study. All the patients were operated upon by the first author. The surgeon used short-floating columellar strut graft on all of his patients between the years 2011 and 2013. After 2013, the surgeon used suture techniques only. Moreover, the open approach was employed in all participants by performing transcolumellar and marginal incisions and dorsal hump reduction, septoplasty, septal graft harvesting, cephalic trimming, and lateral osteotomies. Spreader grafts were performed as required. The patients were divided into two groups depending on the techniques employed. In the first group, columellar short-floating strut grafts were placed for tip modification. The strut grafts were harvested from septal cartilage. In the second group, only sutures were used to modify the tip without any kind of graft. Transdomal, interdomal and septocrural sutures were used in all the patients in this group (group 1: Graft group, group 2: Suture group). Photoshop software CC 2015 (Adobe Systems, San Jose, California, USA) software was used to measure parameters with the Ruler tool for each patient. Nasal projection and nasolabial angle measurements were performed from preoperative, postoperative $1^{\text {st }}$ year, postoperative $3^{\text {rd }}$ year, and postoperative $5^{\text {th }}$ year photos. Goode's method was used to measure nasal projection. Three fixed points including the most projected point of the nose tip, nasion, and and the alar point. In this method, the nose tip protrusion is calculated from the ratio of the distance from the alar point to the most reflected point of the nose tip and the distance from nasion to the most predicted point of the nose tip (Figure 1a). To assess nasal tip rotation, the nasolabial angle (the angle between the two lines drawn from 
the subnasal point to the columella and the upper lip) was measured (Figure 1b).

\section{Statistical Analysis}

Descriptive analysis was performed using GraphPad Prism 7.0 software (GraphPad Software, Inc., La Jolla, CA, USA).

\section{Results}

We included 119 patients in the study. The mean age of participants was 29.2 \pm 7 (range: 21-54). Sixty-two were males while fifty-seven were females. In addition, 67 patients were in the suture group and 52 patients were in the graft group (Table 1). No major complications were encountered in any of the patients (Figure 2, 3).

The mean value of preoperative nasal tip projection measurement was $0.605 \pm 0.07$ and $0.653 \pm 0.08$ in groups 1 and 2, respectively. Postoperative nasal tip projection measurement in group 1 was 0.636 , 0.632 and 0.627 in the $1^{\text {st }}, 3^{\text {rd }}$, and $5^{\text {th }}$ postoperative year, respectively. Postoperative nasal tip projection measurement in group 2 was 0.656 , 0.634 and 0.632 in the $1^{\text {st }}, 3^{\text {rd }}$, and $5^{\text {th }}$ postoperative year, respectively (Figure 4, Table 2).

The mean value of preoperative nasolabial angle measurement was $92.77 \pm 8.5$ and $92.14 \pm 6.7$ degrees in groups 1 and 2, respectively. Postoperative nasolabial angle measurement in group 1 was 107.2, 104.3 and 101.3 degrees in the $1^{\text {st }}, 3^{\text {rd }}$, and $5^{\text {th }}$ postoperative year, respectively. Postoperative nasolabial angle measurement in group 2 was 107.4, 104, and 102.2 degrees in the $1^{\text {st }}, 3^{\text {rd }}$, and $5^{\text {th }}$ postoperative year respectively (Figure 5, Table 3).

There was a significant increase in nasal projection of the patients between preoperative and postoperative $1^{\text {st }}$ year measurements in the

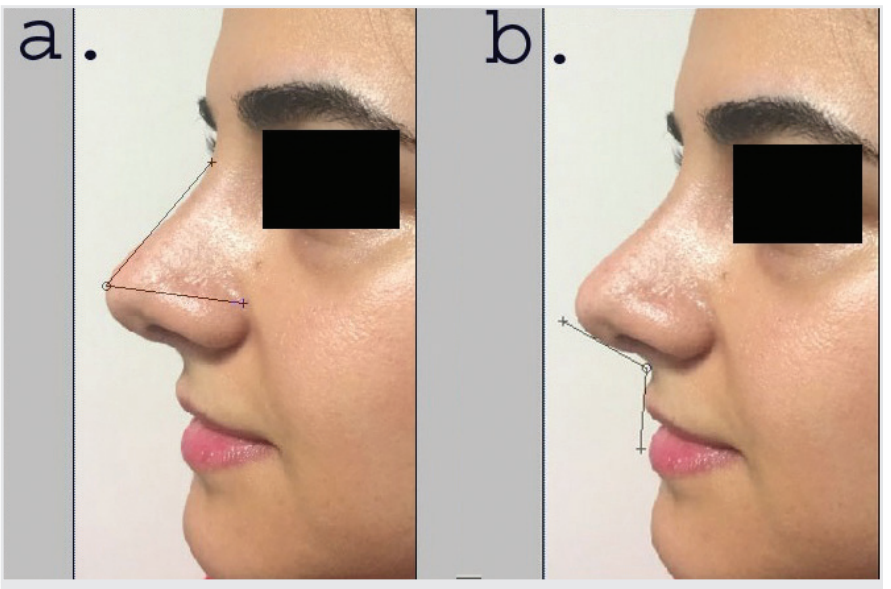

Figure 1. (a) Nasal tip projection calculation from photoshop software. (b) Nasolabial angle calculation from photoshop software

Table 1. Number of patients and sex distribution in each group

\begin{tabular}{|l|l|l|l|}
\hline & Group 1 graft & Group 2 suture & Total \\
\hline Male & 25 & 37 & 62 \\
\hline Female & 27 & 30 & 57 \\
\hline Total & 52 & 67 & 119 \\
\hline
\end{tabular}

graft group. There was no significant difference between preoperative and postoperative $5^{\text {th }}$ year nasal projection measurement across patients in the graft group. Similarly, there was no significant difference between preoperative and postoperative $1^{\text {th }}$ year nasal projection measurements
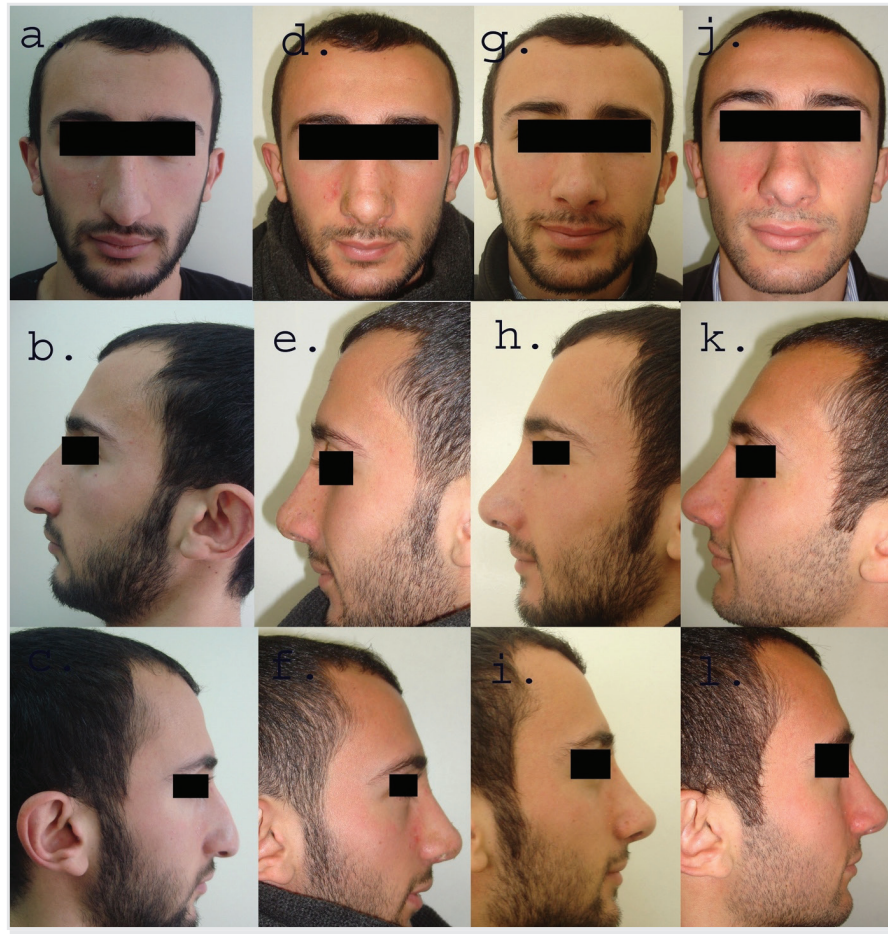

Figure 2. Preoperative $(a, b, c)$, postoperative $1^{\text {st }}$ month (d, e, f), postoperative $3^{\text {rd }}$ year $(g, h, i)$ and postoperative $5^{\text {th }}$ year $(j, k, l)$ photos of patient from the graft group

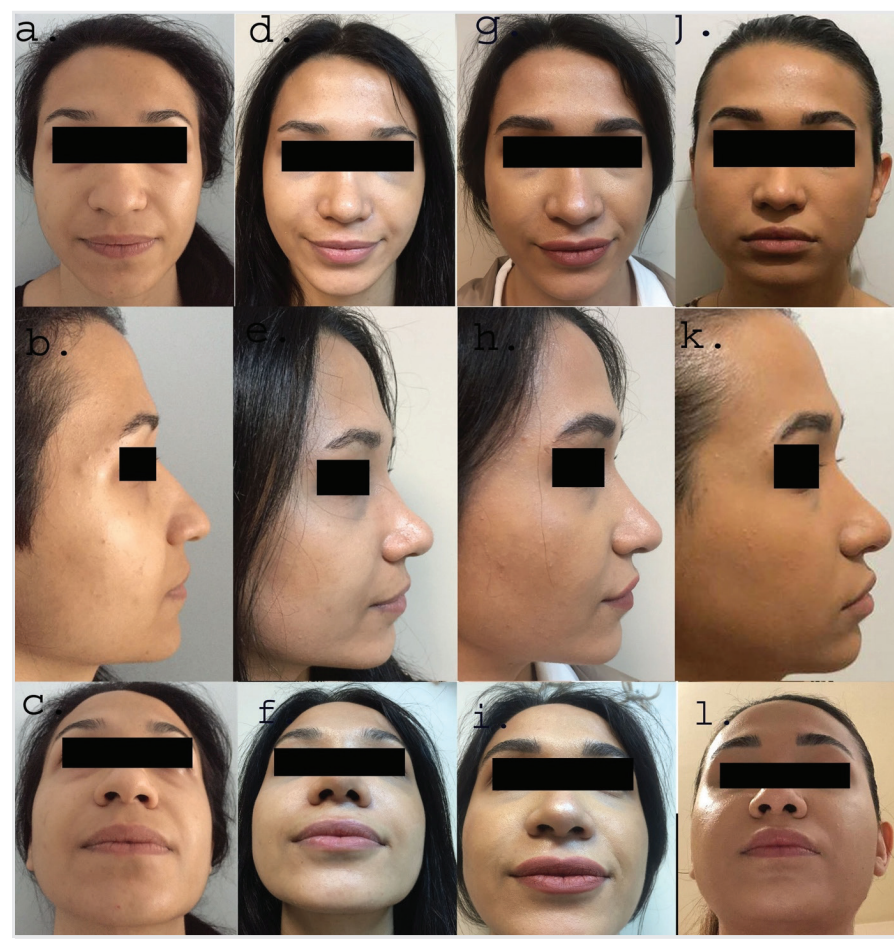

Figure 3. Preoperative $(a, b, c)$, postoperative $1^{\text {st }}$ month $(d, e, f)$, postoperative $3^{\text {rd }}$ year $(\mathrm{g}, \mathrm{h}, \mathrm{i})$ and postoperative $5^{\text {th }}$ year $(\mathrm{j}, \mathrm{k}, \mathrm{l})$ photos of patient from the suture group 
of the patients in the suture group. Moreover, there was a significant decrease in the nasal projection of the patients between preoperative and postoperative $5^{\text {th }}$ year measurements in the suture group (Table 4).

There was significant increase in the nasolabial angle of the patients between preoperative and postoperative $1^{\text {st }}, 3^{\text {rd }}$ and $5^{\text {th }}$ year measurements in the graft group as well as the nasolabial angle of patients between preoperative and postoperative $1^{\text {st }}, 3^{\text {rd }}$, and $5^{\text {th }}$ year measurements in the suture group (Table 5).

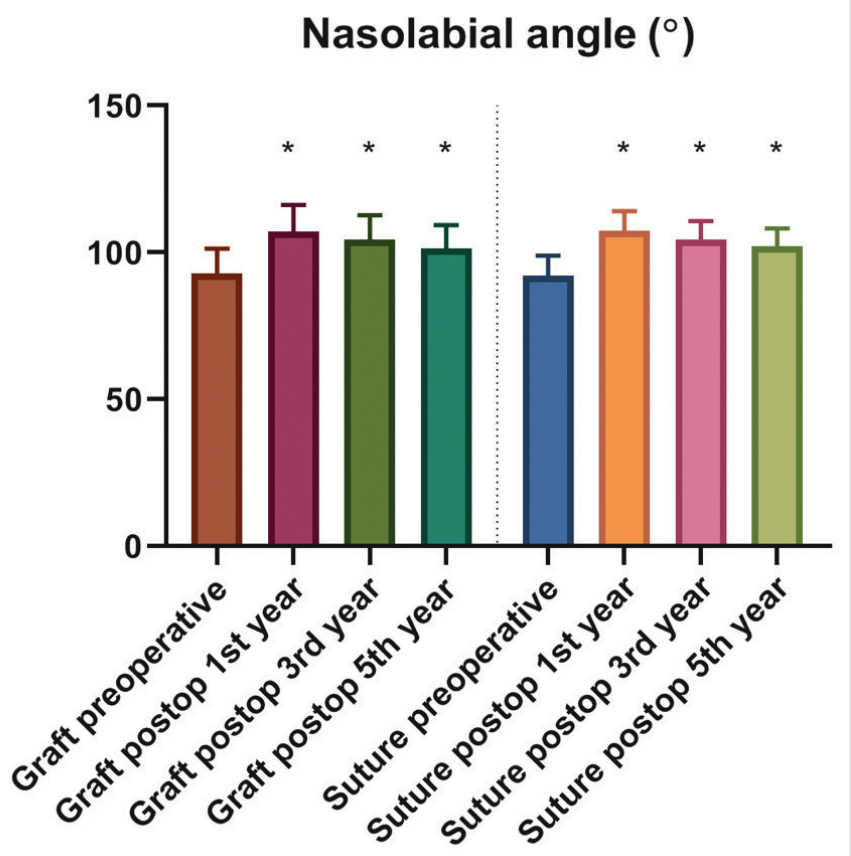

Figure 4. Nasal tip projection measurements

*: $p<0.05$ when compared to preoperative measurements

\section{Discussion}

In tip revision surgery, one of the main goals is to provide the projection appropriate for the facial expression and sex of the patient. Achieving a stable but also mobile nasal tip should be the ultimate goal. If possible, photographs of patients from their youth should be provided. These can provide a healthy planning strategy to the surgical team in the restructuring of the nose tip, especially in patients with a history of trauma or unsuccessful surgical intervention.

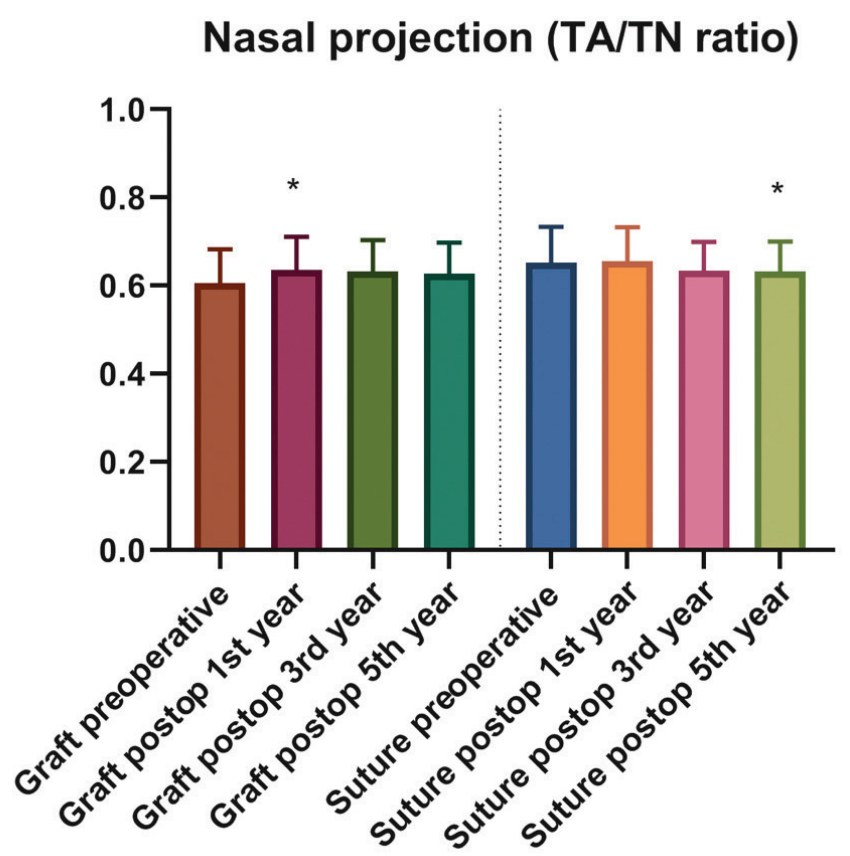

Figure 5. Nasolabial angle measurements

*: $p<0.05$ when compared to preoperative measurements

Table 2. The mean value of nasal projection measurements

\begin{tabular}{|c|c|c|c|c|}
\hline & Preoperative & Postoperative $1^{\text {st }}$ year & Postoperative $3^{\text {rd }}$ year & Postoperative $5^{\text {th }}$ year \\
\hline Group 1: Graft group $(n=52)$ & $0.605 \pm 0.07$ & 0.636 & 0.632 & 0.627 \\
\hline Group 2: Suture group $(n=67)$ & $0.653 \pm 0.08$ & 0.656 & 0.634 & 0.632 \\
\hline
\end{tabular}

Table 3. The mean value of nasolabial angle measurements

\begin{tabular}{|l|l|l|l|l|}
\hline & Preoperative & Postoperative $1^{\text {st }}$ year & Postoperative $3^{\text {rd }}$ year & Postoperative $5^{\text {th }}$ year \\
\hline Group 1: Graft group $(n=52)$ & $92.77 \pm 8.5$ & 107.2 & 104.3 & 101.3 \\
\hline Group 2: Suture group $(n=67)$ & $92.14 \pm 6.7$ & 107.4 & 104 & 102.2 \\
\hline
\end{tabular}

Table 4. Nasal tip projection measurements

\begin{tabular}{|c|c|c|c|c|}
\hline Groups & Mean rank diff. & Significant? & Summary & Adjusted p-value \\
\hline Graft pre vs Graft 1 & -56.29 & Yes & $*$ & 0.0369 \\
\hline Graft pre vs Graft 3 & -52.61 & No & ns & 0.0512 \\
\hline Graft pre vs Graft 5 & -44.01 & No & ns & 0.1028 \\
\hline Suture pre vs Suture 1 & 10.49 & No & ns & 0.6591 \\
\hline Suture pre vs Suture 3 & 46.4 & No & ns & 0.0509 \\
\hline Suture pre vs Suture 5 & 52.14 & Yes & $*$ & 0.0282 \\
\hline
\end{tabular}




\begin{tabular}{|c|c|c|c|c|}
\hline Groups & Mean rank diff. & Significant? & Summary & Adjusted $p$-value \\
\hline *Graft pre vs Graft 1 & -206 & Yes & $* * * *$ & $<0.0001$ \\
\hline${ }^{*}$ Graft pre vs Graft 3 & -167.7 & Yes & $* * * * *$ & $<0.0001$ \\
\hline${ }^{*}$ Graft pre vs Graft 5 & -121.3 & Yes & $* * * *$ & $<0.0001$ \\
\hline * Suture pre vs Suture 1 & -230 & Yes & $* * * * *$ & $<0.0001$ \\
\hline *Suture pre vs Suture 3 & -181.9 & Yes & $* * * * *$ & $<0.0001$ \\
\hline * Suture pre vs Suture 5 & -146.8 & Yes & $* * * * *$ & $<0.0001$ \\
\hline
\end{tabular}

In tip shaping, transdomal sutures, interdomal sutures, lateral crus cephalic trimming are applied as the standard surgical technique in most cases. Strut graft is frequently used to provide tip projection. This graft can be prepared as short and long form. The prepared strut graft can be placed free-floating between the medial crus or fixed to the anterior nasal spina.

Septocrural/septocolumellar suturing technique is frequently used in providing projection as well. Permanent monofilament prolene suture materials or monofilament pds-derived suture materials can be used in the septocrural suture technique. Since prolene suture material is permanent, they can cause exposure and foreign body reactions in the medium, especially in patients with thin skin. The polydioxanone suture maintains the proper nose tip position and stability until wound healing and adequate soft tissue support is achieved. Although there is no certainty about the number of septocrural sutures to be placed, at least two sutures are generally accepted. It is obvious that the fineness of the suture material used and the patient's cartilage tissue support are important to decide on this. In addition to graft and suture techniques, a combination of these or a number of other cartilage-like flap or suspension techniques are also used in projection and rotation improvement.

In our study, columellar strut grafts (short and floating) were used in the first group, while septocrural sutures without grafts were used in the second group. We have seen that projection loss was evident at five years following the surgery in the suture group when compared to the graft group. In a previous study by Şirinoğlu (4), no significant difference in the decrease of projection and nasolabial angle was found in the first month and first year after surgery between the short-floating strut grafts and the two septocolumellar sutures. We predict that this follow-up duration was not sufficient to observe the loss of the projection with the suture group (4). In the study of Rohrich et al. (5), 1,734 patients were evaluated retrospectively for 15 years. Effective results were observed with the use of columella strut grafts in long-term follow-up in cases with inadequate tip support and asymmetry $(2,5)$. In another study, Cerkes (23) described problems related to the insufficient support of nasal tip, and explained the importance of the tripod structure of the nasal tip. The importance of this structure enables us to obtain desired results and aim for the adaptation of the collumellar and lateral crural grafts to be used in reconstruction so as to ensure symmetry and keep the nose tip support at the desired level (23). Cerkes (23) that deals with low dorsum, inadequate projection, and short nose features, short and weak alar cartilage structure is mentioned and racially based differences are mentioned. It is aimed to support the cartilage structure with the grafts which is weak to increase the tip projection (24).

Kuran et al. (3) analyzed postoperative $1^{\text {st }}$ year dorsal length, columellar length, tip projection, tip projection/dorsal length ratios, columellar length/dorsal length ratios and a few more values in a 2-group 18-patient randomized study using cartilaginous graft and tip binding sutures. They found statistically significant values in both groups compared to preoperative measurements in most parameters (3). In another study by Kuran et al. (11), 11 patients were followed for 18 months. Cartilageinous flaps prepared from the lateral crus cephalic sections based on medial crus which minimized the rotational disorders and positively affected the symmetry of the dorsal aesthetic lines. The flaps used had a positive effect on projection depending on the dorsal adaptation points of pedicled cartilageinous grafts (11). Yeşiloğlu et al. (13) evaluated rotation, projection, and supratip deformities of 32 patients on average 2-year follow-up using the lateral cartilage-based cartilage suspension technique. The reversible technique is considered to be the most remarkable feature. The desired results were obtained in asymmetric patient rotations and therefore projection. Patient satisfaction was observed at a high rate (13).

Stephan and Wang (20) used the columellar strut graft effectively in asymmetrical nasal tip repair. Especially they achieved successful results with suture techniques that they combined in deviated noses. The importance of finding the underlying structural disorder before the tip asymmetry correction was emphasized in this study (20).

Cingi et al. (25) have done a comprehensive study on nasal tip sutures. They have detailed the positive effects of various suture techniques on projection and other structural problems. In our study, objective results were found to support these analyzes in patients using both strut grafts and suturing techniques (25). In a previous study the use of columellar strut grafts with the correct indication in patients with inadequate projection was emphasized. The importance of preoperative patient analysis was emphasized (26). Schinkel and Nayak (15) states that nasal tip surgery should be addressed at the initial stages of rhinoplasty surgery. It is necessary to have a good command of the tip anatomy for successful tip modification.

The values we obtained at the end of our 5-year follow-up period of mild and moderate deformed noses operated with the same technique showed that there was a decrease trend in projection and nasolabial angle in both the collumellar strut graft and suture group. The decrease between the first year and third year in the nasolabial angle in suture group was significant in only in suture group. The decrease between the 
first year and fifth year in the nasolabial angle in both suture group and strut group was significant. But despite this decrease when compared with the preoperative nasolabial angle values, positive gain was observed at 5 years in both groups. If we interpret the results from here, it seems that the nasolabial angle values were maintained in the first 5 years follow-up in patients with mild and moderate deformed noses.

\section{Study Limitations}

This study had several limitations. This was a retrospective study and the patients were collected from a single-center. Patient standardization was not perfect and future prospective randomized studies can be beneficial to overcome these limitations and support our findings.

\section{Conclusion}

There was a significant difference in projection with the suture group when compared to the strut group in the postoperative fifth year measurements. This probably depends on the strength of the cartilage and in patients with weak cartilages, the projection was lost without a strut graft at the fifth postoperative year. The projection loss can also be attributed to the presence of deep tissue contraction which the sutures cannot withstand. In cases with strut grafts, the graft support provides a more resistant nose tip support, thus less projection loss is found. The preoperative projection values of the strut group patients we operated were less. Despite this, the long-term projection support was better provided, and the nasolabial angle sufficiently increased despite the decrease in both groups. In projection-related problems, using supporters such as strut grafts is more beneficial in cases where maintaining the projection is critical.

Ethics Committee Approval: The study was approved by the University of Health Sciences Turkey, İstanbul Training and Research Local Ethics Committee (approval number: 2802, date: 16.04.2021).

Informed Consent: Informed consents granted by all patients.

Peer-review: Externally and internally peer-reviewed.

Authorship Contributions: Surgical and Medical Practices - D.A.; Concept - D.A., M.S.; Design - D.A., G.T., M.S.; Data Collection or Processing - D.A., G.T., M.S.; Analysis or Interpretation - D.A., G.T., M.S.; Literature Search G.T., M.S.; Writing - D.A., M.S.

Conflict of Interest: No conflict of interest was declared by the authors. Financial Disclosure: The authors declared that this study received no financial support.

\section{References}

1. Rohrich RJ, Ahmad J. A Practical approach to rhinoplasty. Plast Reconstr Surg 2016; 137: 725e-46

2. Rohrich RJ, Kurkjian TJ, Hoxworth RE, Stephan PJ, Mojallal A. The effect of the columellar strut graft on nasal tip position in primary rhinoplasty. Plast Reconstr Surg 2012; 130: 926-32.

3. Kuran I, Tumerdem B, Tosun U, Yildiz K. Evaluation of the effects of tipbinding sutures and cartilaginous grafts on tip projection and rotation. Plast Reconstr Surg 2005: 116: 282-8.
4. Şirinoğlu $H$. Effect of the short and floating columellar strut graft and septocolumellar suture on nasal tip projection and rotation in primary open approach rhinoplasty. Aesthetic Plast Surg 2017; 41: 146-52.

5. Rohrich RJ, Hoxworth RE, Kurkjian TJ. The role of the columellar strut in rhinoplasty: indications and rationale. Plast Reconstr Surg 2012; 129: 118e25

6. Cingi C, Bayar Muluk N, Winkler A, Thomas JR. Nasal tip grafts. J Craniofac Surg 2018; 29: 1914-21.

7. Afrooz PN, Carboy JA, Mendez BM, Rohrich RJ. Cephalic rotation of the nasal tip. Plast Reconstr Surg 2019; 143: 734e-43.

8. Berghaus A. Modern rhinoplasty: Is there a place for the closed approach? Facial Plast Surg 2016; 32: 402-8.

9. Kamer FM, Pieper PG. Nasal tip surgery: a 30-year experience. Facial Plast Surg Clin North Am 2004; 12: 81-92.

10. Rohrich RJ, Ahmad J. Rhinoplasty. Plast Reconstr Surg 2011; 128: 49e-73.

11. Kuran I, Öreroğlu AR, Efendioğlu K. The lateral crural rein flap: a novel technique for management of tip rotation in primary rhinoplasty. Aesthet Surg J 2014; 34: 1008-17.

12. Özçelik D, Toplu G, Türkseven A, Sezen G, Ankarali H. The importance of the trigeminal cardiac reflex in rhinoplasty surgery. Ann Plast Surg 2015; 75: 213 8.

13. Yeșiloğlu N, Sarici M, Temiz G, Yildiz K, Mersa B, Filinte GT. Hezarfen wings: a lower lateral cartilage-based cartilage suspension technique for the adjustment of nasal tip rotation and projection and the correction of supratip deformity. J Craniofac Surg 2014; 25: 983-7.

14. Daniel RK, Palhazi P. The nasal ligaments and tip support in rhinoplasty: An anatomical study. Aesthet Surg J 2018; 38: 357-68.

15. Schinkel ML, Nayak LM. Nasal tip modifications. Oral Maxillofac Surg Clin North Am 2012; 24: 67-74.

16. Gruber RP, Piper M, Chang J. Commentary on: The nasal ligaments and tip support in rhinoplasty: An anatomical study. Aesthet Surg J 2018; 38: 369-73.

17. Apaydin F. Projection and deprojection techniques in rhinoplasty. Clin Plast Surg 2016; 43: 151-68.

18. Adamson PA, Funk E. Nasal tip dynamics. Facial Plast Surg Clin North Am 2009; 17: 29-40.

19. Constantine FC, Ahmad J, Geissler P, Rohrich RJ. Simplifying the management of caudal septal deviation in rhinoplasty. Plast Reconstr Surg 2014; 134: 379e88 .

20. Stephan S, Wang TD. Asymmetric nasal tip. Facial Plast Surg 2012; 28: 177-86.

21. Rohrich RJ, Malafa MM, Ahmad J, Basci DS. Managing alar flare in rhinoplasty Plast Reconstr Surg 2017; 140: 910-19.

22. Davis RE. Nasal tip complications. Facial Plast Surg 2012; 28: 294-302.

23. Cerkes N. Nasal Tip Deficiency. Clin Plast Surg 2016; 43: 135-50.

24. Nazim C. Commentary on 3D photogrammetric analysis of the nasal tip projection and derotation based on the nasal tip quadripod concept. Aesthetic Plast Surg 2017; 41: 1164-66

25. Cingi C, Muluk NB, Ulusoy S, Söken H, Altıntoprak N, Sahin E, et al. Nasal tip sutures: Techniques and indications. Am J Rhinol Allergy 2015; 29: e205-11.

26. Bitik O, Uzun H, Kamburoğlu HO, Çalis M, Zins JE. Revisiting the role of columellar strut graft in primary open approach rhinoplasty. Plast Reconstr Surg 2015; 135: 987-97. 